\title{
Building Character Education Based on Krik Salamat
}

\author{
I Gusti Made Sulindra, Lahmuddin Zuhri, Juanda \\ University of Samawa, Sumbawa, Indonesia
}

\begin{abstract}
Education is a benchmark of human resources quality and civilization. It refers to the principles of accountability, transparency, and striving for an integrated tradition among education, research, and community services as well as the growth of academic. "Pancasila" and "krik salamat" are the reference of character development, for example, Sumbawa. Indeed, Sumbawaness view that happiness is from the material and immaterial. It is also the biggest part of the grace of God and honor called endowment. "Krik salamat” provides purposes and comforts for character building, while character is a tool for social changes which emphasizes local values, such as justice, truth, rational and deliberation, mutual respect, mutual cooperation, and kinship.
\end{abstract}

Keywords: krik salamat, education, character

\section{Introduction}

Indonesia National Qualification Framework (NQF) (in Indonesian language called “Kerangka Kualifikasi Nasional Indonesia”) classifies character into two parts, namely, general description (character, personality, attitude, ethical, and moral) and specific description (knowledge, skills, and competence) (President Regulation Republic of Indonesia, 2012). According to general description, character carries out in order to get the right social changes that defines the concept of self-determination of a nation. Education and Culture Ministry of Indonesia (2012) held a special study on the implications to prepare the framework as a national qualification standards.

It is necessary to utilize a local value as a principle, because Indonesian people have diversity (Kosumohamidjoyo, 2000, p. 45). So, need assessments are outstanding to understand the diversity, character, culture, customs, religion, language, and technology. Each culture has a picture of proper behavior and is not feasible, then the picture of the behavior concretely formulates in a variety of human childbirth and norms of decency, morality, and religion (Krickhoff, 1991, p. 57).

Character building should be aligned with the values of local wisdom-Sumbawa community. "Krik salamat" contains morale, the spirit of protecting the ecology (nature), family-togetherness, cooperativeness, and monotheism (Juanda, 2015, p. 221). Sumbawaness interpret "krik salamat" as an abundance of grace and salvation, while slamat crickets' term is a grace and safety (Faisal, 1999).

Here, "krik" salamat is not only the material, but also include immaterial, because Sumbawaness (Sumbawa people) look happiness is not only from the material, but the peace of mind which is also the biggest part of the grace of God (Zulkarnaen, 2011). Because of this, the government has launched a reform of

I Gusti Made Sulendra, M.Pd., Department of Technology of Educatiom, University of Samawa. Lahmuddin Zuhri, Dr., associate professor, Department of Law Studies, University of Samawa.

Juanda, Dr. candidate, Department of Indonesian Language Education and Art, University of Samawa. 
education in Indonesia, one good way is to strengthen the curriculum. The curriculum is designed to prepare the Indonesian people to be productive, creative, innovative, and able to contribute to society, nation, state, and world.

\section{Pancasila and Krik Salamat}

"Pancasila" is constitutional agreement of Indonesia, because of this is not allowed to spread propaganda to reject or hate any culture or religion (Latif, 2011). As national framework, it reflects the ethical commitment of Indonesian people to organize public policies which is based on the values and character diversity. It also pretends to set up a system of beliefs, worships, norms, and identity in the sphere (Pobattingi, 1998, p. 8; Latif, 2011, p. 112). It does not only involves universal moral values of religions, but also clearly distinguishes from religion. In State Constitution Republic of Indonesia (Undang-Undang, 1945) stated that Indonesia was based on the belief in one God and civilized humanity. Indeed to Article 29 stated that the guarantees the freedom of each citizen to profess his/her own religion and to worship to his/her religion or belief.

"Krik salamat" is series values which contains moral, spirit of ecology, togetherness, cooperativeness, and monotheism (Faisal, 1999, pp. 194-195). "Krik" means endowment or gift from God, while "salamat" is safety. Endowment is not only material, but also immaterial. "Krik salamat" contains local values or local wisdoms which build region or national character. It is link with "pancasila" as a source of value and national character. Besides that, Sumbawaness settle monotheism and Islam as the guideline in establishing a culture and civilization in "Tana Samawa” (Sumbawa region).

The aim is to keep the existence of ecology, to receive blessing, and to benefit the Sumbawaness. It combines the value of cultural with sharia of Islam. According to Lembaga Adat Tanah Samawa (Samawa Indigenous Institutes) is “adat barenti syarah, syarah barenti kitabullah" (culture adheres sharia, and sharia holds on Koran). This implies that Sumbawaness preserve religion, then also maintains culture.

\section{Justice and Truth}

Justice derived from "al-adl” (Arabic) which literally means straight, balanced, and fair, while justice means treating everyone with the principle of equality without discrimination (Latif, 2011, p. 112). The role of the state in social justice, such as: (a) fair relations at all levels; (b) equality of opportunity; (c) facilitating access to the necessary information, services, and resources; and (d) participation on decision-making for everyone. The justice is also not limited to the fulfillment of which are economic prosperity, but also related to the emancipation efforts.

Sumbawaness view justice from morality and monotheism, while "Koran" is reference to justice. "Krik" looks for justice in the sense of putting one in place, the same taste, and the same amount. This concept is similarity with equilibrium or may be associated with a balance of rights and obligations. Justice in economic relations between the community and its citizens, with all the pleasures and always split the load evenly to their nature and their respective capacities. This is what gave birth to distributive justice. The embodiment of justice should not only be based on the principles of rights and legal-formal, but must also be accompanied by a sense of compassion. In this case, the same as the value of "saling pedi" (mutual care) and "saling sakiki" (help each other) in "krik salamat” (Faisal, 1999, p. 49).

Then, the principle of truth. It reflects in "saling satotang" (remind each other). It manipulates humanity toward a goal that is good and right desired by Allah Subhanahu Wa Ta'ala (SWT). Islamic law serves as social 
engineering, "Nahi Munkar” (good and bad) function as social control.

This principle is immense role and usefulness for religious life, community, and state. As fourth principle of "pancasila," democracy led by the inner wisdom consultative or representative contains some of the characteristics of the nature of Indonesia. In 1945, Undang-Undang stated that sovereignty was based on democratic and consent. In other words, democracy contains characteristics: (a) citizenship (sovereign people); and (b) consultative. However, Hatta (1970) advocated the need to tread on the traditions of the village consultative. However, he cautioned that democracy was not suitable to all country.

Consensus practices in villages by taking the decision to an agreement (Huntington, 1991; 1992). At the state level, there are various parties and political opposition, so the decision by unanimous consensus is difficult to achieve in the House of Representatives. Therefore, it must be possible decision by majority vote. Hatta (1970) (as cited in Maryono, 2015) emphasized that consensus imposes as prevalent in countries totalitarian was incompatible with the idea of democracy of Indonesia, because it was incipient as a result of the deliberations.

The principle "musyakarah" always used by Sumbawaness in deciding Sumbawaness' problems, such as uphold family values, mutual respect, truth, and consensus which protect "Tauhid” (monotheism) as the owner of the universe and life. Thus, "musyakarah" is used to solve Sumbawaness problems. It is also making the best decision in the society which logically and openly with the pattern of effective communication (Mantja, 1984).

\section{Mutual Respect and Honor}

The principle of "saling satingi" (mutual respect and honor) becomes part of Sumbawa culture, promulgates to respect among people despite their status as a corpse. So, "saling satingi" is important in any activities of Sumbawaness, for example, to determine the pattern of ground scare and supervision of farm animals. These are done with deliberation in a spirit of mutual respect and honor, then private is marriage in customs of Sumbawa (Juanda, 2015, pp. 222-223).

"Saling satingi" lies in Sumbawaness, so there is no difference between Sumbawaness whether the rich or the poor. The differences between them are only the level of faith and devotion to God Almighty, while economic status does not used in the culture of Samawa. "Saling satingi" is as part of the glorified humanity .

\section{Mutual Cooperation and Kinship}

The principle of family is togetherness. It is a unity that cannot be separated from each other. This principle should also be accompanied by emancipation and participation, so that kinship and togetherness becomes the basis for participation (Swasono, 1997). It is the basis for emancipation, there will be no participation without emancipation. Family must also be supported by the value of "saling tulung" (mutual assistance). This is a follow up of the real the principle of Sumbawaness in helping others, mutual assistance and cooperation in accordance with the traditions of the Indonesian people (Muhammading, 2009).

Sumbawaness emphasize to live in harmony and peace for the differences, whether it is a difference of opinion and perspective as well as others (Juanda, 2015, p. 223). Departing from diversity is to create a sense of egalitarian among Sumbawaness. It can be said that the Sumbawa Kingdom influenced by foreign culture, as it has been featured on the map of life diversity. The values and the spirit of equality become the foundation of building mosques. All citizens have equal rights before the law, this equation redeem boundary rich and poor, leaders and people. They are all the same equal or the same level, regardless of skin color and ethnic-language. 


\section{Conclusion}

"Krik salamat" considers that power is limited by the people. The power is monitored by the people, and also supervised by the Lord. Consequently, it should be transparency and accountability. "Krik salamat" and "pancasila" could provide moral and philosophical foundation for the democratic system, laws, fair, and moral for Sumbawaness. "Krik salamat” refers to build national character education, such as justice and truth, rational and deliberation, mutual respect, mutual cooperation, and kinship.

\section{References}

Faisal, S. S. (1999). Budaya kerja masyarakat petani sumbawa: Kajian strukturasionistik (Ethos culture of sumbawa farmer: Structurasionistic studies). Surabaya: Airlangga University.

Hatta, M. (1970). Sesudah 25 tahun (After 25 years). Jakarta: Djambatan Press.

Huntington, S. (1991). Democracy's third wave. Journal of Democracy, 2(2), 12-34.

Huntington, S. (1992). The third wave: Demoratization in the late twientieth century. Norman \& London: University of Oklahoma Press.

Juanda. (2015). Pembelajaran bahasa Indonesia berkarakter melalui sastra tau samawa (Indonesian language learning characterize on samawa literature). In Suharni (Ed.), Role of research and technology to enhance national competitiveness in global era. Yogyakarta, Indonesia.

Kosumohamidjoyo, B. (2000). Kebinekaan masyarakat Indonesia: Suatu problematika filsafat kebudayaan (Indonesian in diversity: Philosophy studies). Jakarta: PT Grasindo Press.

Kriekhoff, V. J. L. (1991). Kedudukan tanah dati sebagai tanah adat di Maluku Tengah, suatu kajuan dengan memanfaatkan pendekatan antropologi hukum (Status of dati land as indigenous in central Moluccas: A study by utilizing the legal anthropological approach) (Doctoral thesis, University of Indonesia, Doctoral Program of Law Studies).

Latif, Y. (2011). Negara paripurna: Historisitas, rasionalitas dan aktualitas “pancasila” (Civilized state: Historicity, rationality, and actuality of "pancasila”). Jakarta: Gramedia.

Maryono. (2015). Bung Hatta, proklamator, ilmuwan, penulis, dan karya-karya: Sebuah analisis bio-bibliometrik (Mr. Hatta, proclamator, scientist, author, and his works: Bio-bibliometric analysis). Berkala Ilmu Pengetahuan an Informasi (Journal of science and information), 11(2), 24-35.

Mantja, L. (1984). Sumbawa di masa lalu: Suatu tinjauan sejarah (Sumbawa in the pass: Historical review). Surabaya: Rinta Press.

Muhammading. (2009). Profil daerah kabupaten Sumbawa (Profile of Sumbawa regency). Sumbawa: Sumbawa Regency.

Pobattingi, M. (1998). Relevansi dan masalah nasionalisme (Relevance and nationalism problem). Jurnal Ilmu Politik (Journal of Political Science), 16, 56-64.

President Regulation Republic of Indonesia. (2012). Indonesia National Qualification Framework (No. 8). Jakarta: State Secretariat.

Swasono, S. E. (1997). Pasar bebas yang imajiner: Distorsi politik dan pertentangan kepentingan internasional (Free imaginer market: Political distortion and contrary to international interest). Malang: Majalah.

Undang-Undang, D. T. (1945). State Constitution Republic of Indonesia. Jakarta: State Secretariat.

Zulkarnaen, A. (2011). Tradisi dan adat istiadat Samawa (Tradition and custom of Samawa). Yogyakarta: Ombak Press. 